\title{
Bible Leaves! Bible Leaves! Hellenism and Hebraism in Melville's Moby-Dick
}

\section{Citation}

New, Elisa. 1998. Bible leaves! Bible leaves! Hellenism and hebraism in Melville's Moby-Dick. Poetics Today 19(2): 281-303.

\section{Published Version}

http://dx.doi.org/10.2307/1773443

\section{Permanent link}

http://nrs.harvard.edu/urn-3:HUL.InstRepos:4726201

\section{Terms of Use}

This article was downloaded from Harvard University's DASH repository, and is made available under the terms and conditions applicable to Other Posted Material, as set forth at http:// nrs.harvard.edu/urn-3:HUL.InstRepos:dash.current.terms-of-use\#LAA

\section{Share Your Story}

The Harvard community has made this article openly available.

Please share how this access benefits you. Submit a story.

\section{Accessibility}




\title{
Bible Leaves! Bible Leaves! Hellenism and Hebraism in Melville's Moby-Dick
}

\author{
Elisa New \\ English, Pennsylvania
}

\begin{abstract}
Bible Leaves! Bible Leaves!': Hebraism and Hellenism in Melville's Moby-Dick" argues that Herman Melville is Hellenism's severest American critic, and his greatest book, a sustained defense of the Hebraic "letter." Using a range of devices to link his monomaniac, Ahab, with the Greek and Christian subordination of history to reason, Melville exposes the damage to historical knowledge, as well as the characterological and institutional damages, that too singleminded a pursuit of the "spirit" may wreak: In Melville's version, Unitarian ministers and revivalist preachers as well as his own later, allegorizing critics join with Ahab in violent depredations on historical truth. On the other hand, Ishmael, as the essay goes on to argue, is Melville's Hebraist par excellence. Melville draws on Carlyle, on John Kitto's classically historicist Cyclopaedia of Biblical Literature, and on the Book of Ecclesiastes to fashion Ishmael as a hero of Hebraic restraint and a champion of Hebraic prolixity. Moby-Dick, the great whale, is also Moby-Dick, the redoubtable text, which, in surviving Ahab's assault, sustains the viability of the letter and of history beyond the reach of reason.
\end{abstract}

\section{Burning the Bible Leaves: Essence and Text}

At a crucial moment in Herman Melville's Moby-Dick, in the chapter just preceding its narrator-hero Ishmael's closest shave with annihilation, the

The author wishes to acknowledge editing assistance from Bruce Snider as well as from David Stern and the board of Poetics Today.

Poetics Today 19:2 (Summer 1998) Copyright @ 1998 by the Porter Institute for Poetics and Semiotics. 
reader encounters this description of the last fiery step in the processing of whale oil: "Bible Leaves! Bible Leaves! This is the invariable cry from the mates to the mincer. It enjoins him to be careful, and cut his work into as thin slices as possible, inasmuch as by so doing the business of boiling out the oil is much accelerated, and its quantity considerably increased, perhaps increasing its quality" (Melville 1967: 351). Melville's caustic allusion to "Bible Leaves!" makes it amply clear that his mincer is a satirized minister. Traducing the materiality and history of the world's body in pursuit of its perfect spirit, this cassocked divine is one of Melville's many figures of a sacrificial and deadly Christian Hellenism, whose essentialist legacy Melville opposes with all the textual resources he can marshal. In another context, the analogy between the rendering of whale fat and the extraction of essence from Scripture might seem merely playful. As it is placed under the chapter heading "The Cassock," however, the humor of the comparison is darkened by the ambiguous character of the figure presiding over the operation. This tableau of the tireless priest feeding leaves to the fire and working, moreover, in an apron fashioned from the whale's own stupendous penis is calculated to elicit laughter. But the image's sportiveness only half conceals its cruelty. Literally enrobed in the virtu of the creature he assaults, the mincer raises all the ambiguities of a Christianity extracting light from the flesh's torment, Word from the wastage of words. If Melville's oil-anointed "mincer" is a stooge of logocentrism in this scene, it is well to remember that he is its scourge as well.

Melville's ferocity in this regard makes him, I want to propose, Hellenism's severest nineteenth-century American critic and makes his greatest book a sustained defense of the "letter," not only anticipating but in certain ways setting the agenda for our own era's defrockers of the Logos. Jacques Derrida demurs to specify too baldly the costs of the Greek and Christian "gift of death." Derrida allows only that the "infinite and dissymmetrical economy of sacrifice is opposed to that of scribes and Pharisees. . . . It refers on the one hand to the Christian as against the Judaic, and on the other hand to the Judeo-Christian against the rest" (Derrida 1992: 107). Melville, by contrast, doubts that scribe and philosopher, Hellenist and Hebraist, can ever join across a hyphen. He names philosophy's triumphalist violence without compunction. His Christian "archbishoprick," functionary of "the pit" and cousin to Canaris (who drove the famed Greek "fire-ship"), pursues God and death at one time; he burns for a Spirit whose incarnate presence, whose very text and flesh, he must immolate to know. Posted where the try-pots cast their flames, this exegete is a figure of a Hellenism from whose infernal power only "unchristian Solomon"-the Hebraist par excellence-can rescue Ishmael. 
Closer attention to such passages should alter our understanding of what transgression Melville meant when he wrote to Hawthorne in 1851 , "I have written a wicked book, and feel spotless as the lamb" (Melville 1967: 566), or when, in "The Advocate," he frets lest Moby-Dick be deemed "some hideous and intolerable allegory" (177). Ultimately, Melville's wickedness is more thoroughgoing and original than influential accounts of the book's romantic reinscription of Satan's rebellion will suggest. To be sure, although the allegorical struggle of Ahab against an inscrutable power grips readers to the present day, no reader can long ignore the way in which Ahab, with his sublime quarrel, becomes harder and harder to locate amid the book's very efflorescence of leaves, amid the "sheds and shanties" - as Melville called them - of its prodigious textuality. Moreover, although the honor Melville's greatest work too tardily earned might never have come without that work's unification as an allegory, it is also true that MobyDick has ever discommoded defenders of its unified, or allegorical, structure. "Blubber is blubber," Melville wrote in an $185^{\circ}$ letter to Richard A. Dana, warning that his book would be "ungainly as the gambols of the whales themselves" (Melville 1967: 552). Whatever one's final disposition to the experience of Moby-Dick's "deglutition" (as one early reviewer described the sensation of reading Moby-Dick), one soon enough discovers in it less an adventure narrative, a romantic quest, or a sublime allegory than a massive compendium of knowledges exceeding and outlasting the selfconsumption of its Hellenic magnifico. Moby-Dick is not an antinomian, or even impious, passion play but an exhaustive and exhausting roster of rhetorical, mechanical, and exegetical maneuvers-a technician's or librarian's or pettifogger's tale. Melville's "wickedness," as I will use these pages to show, rests chiefly in the challenge he offers to Hellenic/Christian essentialism in the unmistakably Hebraic textualism of the book's form.

And in the person of Ahab's engaging nemesis: the circumlocutory Ishmael. Of late, Ishmael's vagrancy and landlessness have proved enormously appealing to a postmodernism that finds few better glosses of its tenet of constructedness than Ishmael's famously skeptical self-identification: "Call me Ishmael." Yet it is crucial to note that Ishmael is not just any wanderer, not just any embodiment of indeterminate essence. Purveyor of historical wisdom as opposed to perfect intellectual truth, Ishmael is the selfsame scribe whose Hebraic ethic St. Paul stigmatized in Galatians 4: 21-27. There the apostle traced the superannuated Law to Abraham's outcast son, the orphaned Ishmael. Like this scribal Ishmael, the wandering ways and digressive narrative style of Melville's Ishmael disperse in enumeration and action the very unified Word that Pauline lovers of the Logos would penetrate and plumb. Ishmael's textual prodigiousness, his eager- 
ness to substitute action and talk (seafaring, landlessness, and the piling up of commentary) for the verbum infans ("pistol and ball" and the igniting of meaning) are proof against the dismemberment and madness that Ahab's more normative, though also deadly, love of knowledge courts. Finally, Melville's recanting of Paul, his rejection of Hellenic ontology in favor of Hebraic wisdom, is best described by Ishmael's attractiveness and by Ishmael's survival. Through the offices of Melville's Hebraism, Ishmael is preserved by history, while the febrile monist, Ahab, is consumed by Christian time.

Always implicit in Americanist criticism of Moby-Dick, this tension between Hebraism and Hellenism has been understandably slow to emerge as an explicit topic of inquiry. This may be because Melville's Hebraism has been for so long under our noses in his prodigious biblicism. This biblicism of Moby-Dick has never been doubted; nor, for that matter, has Melville's omnivorous absorption of Greek philosophy of all kinds. For the first generations of the text's rediscovery, however, critics were kept occupied with the task of excavating Melville's nearly inexhaustible veins of scriptural and classical references for their thematic import. Such important studies of the 1940s and 1950s as Melville's Religious Thought, by William Braswell; Melville's Use of the Bible, by Natalia Wright; and especially Melville's Quarrel with God, by Lawrence Thompson, unearthed the allusive richness of Melville's text, proving beyond doubt Melville's immersion in and sophisticated engagement with the process of scriptural interpretation. These studies made possible, and led naturally to, the more hermeneutically attuned studies of the 1960s and 197os: Ursula Brumm's American Thought and Religious Typology, T. Walter Herbert's Moby-Dick and Calvinism, Rowland Sherrill's Prophetic Waters, Bayard Cowan's Exiled Waters, Robert Zoellner's Salt-Sea Mastodon, and Giles Gunn's The Interpretation of Otherness, texts whose discovery of Moby-Dick's deliberate polysemy made almost inevitable the omnibus volume edited by Hershel Parker and Harrison Hayford, Moby-Dick as Doubloon. These works, informed in method by what we now recognize for first-wave deconstruction, gave foundation to the more explicitly historicized though still hermeneutically inflected inquiries of Lawrence Buell, Barbara Packer, Ann Douglas, Michael Colacurcio, and Stanley Cavell, whose researches into the interpretive assumptions of Melville and Hawthorne, Emerson and Thoreau led them all, by different paths, to the interpretive practices of the antebellum Protestant establishment.

This more recent historicism - which also integrates and registers (though it does not always corroborate) certain Foucauldian insights about power that Sacvan Bercovitch transposed in the American key-has en- 
abled us to see Moby-Dick not simply, as first-wave critics did, as a work of antinomian impiety, and not simply, as critics hewing to emergent Derridean paradigms did, as a text manifesting a certain conveniently postmodern hermeneutic self-consciousness and undecidability. In the light of the newest research, Moby-Dick offers a view into a vernacular American Hebraism as it emerged from a crucible of a romantically inflected Christian hermeneutics. It reveals America's absorption and negotiation of the Hebraism/Hellenism problem in the particular, ideologically significant historical form in which it first appeared: a sectarian contretemps over the disunified Bible of the Higher Critics. The antebellum struggle of liberal and orthodox Protestants striving to reconcile Scripture's historicity with its eternal truth informs and shapes the very matter of Moby-Dick, a text Lawrence Buell calls, accordingly, a key "document in the history of the clash in American and specifically Northeastern Puritanism between Reformation Calvinist and Enlightenment Unitarian cross currents" (Brodhead 1986: 69). Or, as T. Walter Herbert concurs in his more recent work, new inquiries into Moby-Dick as a text thematizing counterposed religious "forms of understanding" do more than address religious "themes": Beyond this, they open lines of communication between narrowly focused studies of Melville and his antebellum world and broader interdisciplinary researches into the history and transmission of religious ideas.

As these following pages will propose, Ishmael's eclectic historicism directly serves Melville's own anti-Platonic and, as he puts it, "unchristian" agenda. Letting Ishmael's method inform the composition of his text, Melville composes his greatest work to expose the perennial struggle of Hebraic historicism and Hellenic monism. Further, the text of Moby-Dick becomes an archive and a chronicle of this struggle, which, renascent from age to age, finds ever fresher opportunities for expression: Melville casts a wide net for Hellenists, and the net comes up full. Thus, the wicked King, Ahab, will be shown to be an ancestor to Paul, whose heir, the archbishoprick, sires fallen angels of manifold description. Crazed captains and Higher Critics disclose a common allegiance to essences obtained by whatever means should be necessary. Unitarian rationalists, their methods obviating their messages, evince views ultimately indistinguishable in their ahistoricism from those of Calvinist hardliners. Drawing, thus, on a temporally eclectic and stylistically heterogenous wealth of documentsscreeds from the Unitarian controversy and the works of the self-styled Hebraist Thomas Carlyle; Higher Critical classics and the Hebrew texts of Job, Jonah, and Ecclesiastes; German romantic theory and high Calvinist dogma-Melville makes Moby-Dick the workshop of a vernacular American Hebraism, the value of whose "unchristian" way and the wis- 
dom of whose redoubtable apostle, Ishmael, his book's own textual density affirms. What shall we do with the leftover letter? This is the question Melville understood Western culture to set for him. Moby-Dick, Melville's effective answer, emerges from his reckoning of the safest course around the Hellenist's "gift of death."

\section{Hellenism: Cetology to Theology}

Melville was not unprepared to see his text allegorized or to see his sage chronicler, Ishmael, eclipsed by his more magnetic philosopher, Ahab. He well knew that the historicity of divine expression-implying a Divinity of much patience and prescribing a human way of some deliberateness - is not gladly suffered by Truth's more precipitous adherents. The negligible prestige of Hebraic method, emblemized in the low rank of the narrator and ordinary seaman, Ishmael, is a home truth Melville underscores throughout Moby-Dick by giving allegorists and lovers of Truth a status eclipsing that of the mere scribes ("burrowers" or "sub-subs" or "consumptive ushers") who toil to unearth the very letters and leaves these more august princes of light (archbishopricks and their minions) burn. The latter, looming over the whalemen's pulpit, supervise the maritime coffers and command the quarterdeck. Moreover, these figures claim a dominion in the narrative that the critical literature-especially the earliest literature-granted them as well.

To be sure, notwithstanding guts and blubber by the ton, a full crew of motley personalities, and an inventory of technical instruction and hardware surely unmatched in Western literature, Moby-Dick's early promoters did not hesitate to read all the excesses of Melville's text as the necessary, if baroque, accoutrements of Ahab's sublimely Satanic mission: in Lawrence Thompson's memorable phrase, to "pique-God" (Thompson 1952: 204). In quest of an iconic, if unavoidably complex, fix on Moby-Dick's heterogeneities, Thompson's devotion to allegorical synthesis enables him to rationalize away prodigious amounts of textual heterogeneity, appealing, when he must, to the synthetic powers of the reader, whose expectation of the book's ultimate unity he makes sure to flatter in advance: "Melville sometimes doubles and triples and quadruples the symbolic values of an image; but this need not be viewed as inconsistent or confusing to a reader who is willing to hold all emblematic values so tentatively that he may follow Melville's hints to relinquish temporarily those emblematic values in order to make room for the establishment of values which enrich the whole" (ibid.). Allegorical relations of identity, as Thompson conceives them, need not be held to strict one-to-one standards of correspondence 
because, as in Edwin Honig's contemporaneous account, allegory may be understood to "make relationships significant by extending the original identities of which they are composed with as many clusters of meaning as the traffic of the dominant idea will bear" (Honig 1959: 114).

Hindsight makes clear just how much this kind of New Critical analysis (which, after T. S. Eliot's example, often derided the romantic object) nevertheless depended on certain heuristic principles directly informed by the German romantic methodologies of sacred interpretation. Honig's work, like Thompson's, evinces an implicit faith in textual unity reinforced, not incidentally, by the reigning Hellenism of the day: that of Northrop Frye $(1957,1982)$, whose architectonic "anatomies" did not so much dissect as reassemble, making out of cryptic images and generic chaoses symphonic "great codes" capable of rationalizing and organizing any amount of "traffic." Frye's work, which wedded sacral Christian value to New Critical method, refitted for modern literary criticism the sturdily braced hendiadys of textual unity and aesthetic value that had proven so useful to romantic theorists, who had themselves adapted "supernatural" (theological) criteria to "natural" (poetic) ends. Indeed, behind Thompson and Honig and Frye is none other than Coleridge himself, casting the template of the great code: "The common end of all narrative, nay of all poems, is to construct a series into a Whole: to make those events, which in real or imagined History move on in a strait line, assume to our Understandings a circular motion - the snake with its Tail in its mouth" (Abrams 1971: 271). And right behind Coleridge, of course, are the late-eighteenthand nineteenth-century apologists for biblical unity. Coleridge's metaphor, with its explicitly mythological allusion, itself Hellenizes Johann Gottfried von Herder's project of making integrated myth from the Higher Criticism's heterogenous findings, of turning to secular use the older Christian belief in the Word that gathers all words to it.

Coleridge's defense of unity in the poem was, of course, fated to be the most successful action in a rearguard intellectual campaign to stave off the imminent collapse of the entire intellectual edifice that the Bible's unity had mortised. The unity of the singly authored poem-sustained into the 195 os and 196os-would defer for more than a century the fragmenting effects the Bible's historicization visited on other human sciences. For as the researches of the critics emerged and were translated and disseminated beyond Germany, the unified Scripture had come to be seen not as God's will revealed in all its perfection but as a scrapbook of beliefs pieced together and taken apart countless times before the vivisection of the Higher Critics even commenced. All through the nineteenth century and on both sides of the ocean, the struggle to reconcile standards of 
intellectual probity (reason) with "higher," more spiritual notions of truth (insight, value, meaning) united sectarians and scientists, as intellectuals of all stripes sought to preserve a version of the true which, though vast, might be compassed, and which, though complex, might retain some semblance of "intellectual beauty." The alternative to this beauty was one that Connop Thirwall, in a widely read English preface to Schleiermacher, described vividly when he likened the sorry Scripture of Melville's comingof-age to a great cadaver, its picked-over and patched-together carcass a grotesque incarnation of knowledge bereft of reason. No Word, all flesh; no Logos, all letter. Indeed, Thirwall's Scripture, a great dismembered beast, uncannily predicts the material and cetological, as opposed to spiritual and theological, light in which Melville will cast his own chosen object of knowledge, the whale: "Its peculiarity is, it is neither a full body nor a dry anatomy; it rather presents the appearance of a disjointed skeleton in which some of the bones are missing; others are out of their place, and the interstices are here and there covered with a fragment of skin or flesh" (from Thirwall's introduction to Schleiermacher 1825: xxx).

This most formidable intellectual and spiritual challenge of the early nineteenth century - the unification of the disjointed Scripture - was perhaps nowhere taken more seriously than in Melville's New England. At no time in America until the ascendancy of the New Criticism was the premium on unity - literary and theological wholeness understood as one "grace" - so ferociously defended as during the incubation period of MobyDick, and in no intellectual community more than in the Andover/Harvard corridor that was Melville's intellectual milieu. The campaign for some semblance of scriptural unity filled the works of the men who were Melville's childhood pastors and spilled from issue to issue of the journals he made his quotidian reading. It is indeed likely that Melville read Thirwall's preface: As Barbara Packer reminds us (Bercovitch 1986: 72), Thirwall's text, translated into English in 1825, and offering a handily condensed version of the major discoveries on the Continent, was the single most consulted English introduction to the Higher Criticism, a text from which Emerson, for instance, "cribbed shamelessly" (ibid.: 75). Whether or not Melville read this particular text, scholars of Melville's reading confirm his exposure to the debate raging in number after number of the Christian Register, the Christian Examiner, and other clerical publications of the day (Bercaw 1987; Sealts 1988). By perusing these journals, Melville could follow the parries and thrusts of liberal and orthodox, Unitarian and New Light, scholars and churchmen defending biblical unity-the Spirit - against the incursions of the Higher Critical method.

A front-page editorial in the Christian Register of 1849 , for instance, re- 
veals that the presumption of biblical opacity, heterogeneity, and disunity had become so commonplace that where exegetes had once fretted about how faith was to survive scriptural obscurity, now revisionists deemed a belief in textual heterogeneity requisite to faith. The editorialist endeavors to stem this tide, writing, "We cannot conceive why a statement must be difficult to be understood, or susceptible of diverse interpretations, to be an article of faith." Similar assurances as to the compatibility of textual unity and spiritual good order were to be found everywhere, as in a July 1848 issue of the Quarterly Review, where a reviewer of Neander's Life of Christ is moved to contend, "The advantages of studying the life of our Savior in a work where all is harmonized and consecutively arranged are very great. Only in this way can the unity and symmetry of his life be properly appreciated. Neander . . . shows that out of what the rationalists call chaos, 'the spirit of the Lord' can bring forth beauty and order" (Quarterly Review 1848: 352). Such passages reflect the typical interpenetration of unity as a hermeneutic value and unity as a literary grace that characterized the period. Symmetry is a textual virtue that underscores the holiness of the Savior's life; holiness, conversely, is conceived in aesthetic terms.

Now it was, of course, the absence of any supervening literary unity in the very book that set the standard for this unity-the Bible - that left scholars, liberal and orthodox alike, with their most formidable difficulty: how to keep both Scripture's reason and its regnancy? How to preserve the sanctity of what the text actually said (its integrity as a perfect document, revealed by God) against what it might say to us (its power and efficacy in inspiring and guiding faith)? In this endeavor, both sides were encamped on slippery slopes. Orthodox defenders of the Bible's literal truth fell prey to scholastic contortions - and did so for the sake, sometimes, of textual minutiae boasting scant power to inspire. Liberals, on the other hand, were beset by temptations to trim for the sake of the text's "spirit," or its applicability to the Christian life. And once the text was yielded to its applications, to criteria of relevance or meaning, once liberal scholars allowed themselves to excise just this or that small historically unpalatable fact as an interpolation or textual corruption, then the very fabric of revelation began unraveling. The exegete tampering with the letter of the text for the sake of its spirit stood in danger of contaminating sacred history. In sum, scholars of both stripes carrying the old Pauline banners of "letter" and "spirit" found themselves liable to be embarrassed by the very methods on which their dignity was staked, by the incoherence their methods wrought. In the thick of this debate, Melville uses Moby-Dick to reflect on, and ultimately to expose, the essential hostility to history compromising the unifying efforts of liberal and orthodox interpreters alike. 
Throughout the text of Moby-Dick, Melville seizes opportunities to show how orthodox oversolicitousness of biblical authority leads quickly to absurdly contrived kinds of literalism. Peleg and Bildad's transparently selfinterested reading of biblical "lays" is one illustration of this, but the most sustained illustration is probably to be found in "Jonah Historically Regarded," a chapter Melville wrote with that Higher Critical mainstay, John Kitto's 1845 Cyclopaedia of Biblical Literature, at his side.

Improvising waggishly from Kitto, Melville begins the chapter by introducing the reader to a "Sag Head fisherman" whose name first suggests the critique of overburdened ratiocination to follow. Melville finds his heavyheaded salt undergoing a crisis of faith precipitated by - what else? - the inconsistency of biblical whale narratives with his own life experience at sea. To ease his sailor's spiritual crisis, Melville supplies the services of an orthodox exegete whose far-fetched positivist posturings will so strain ordinary credulity as to prove caustic to faith. Giving this exegete a platform, Melville allows the suavity of orthodox positivism to ensnare itself, as the whaleman's doubts are first laid to his ownership of "one of those quaint old-fashioned Bibles, embellished with curious, unscientific plates" (Melville 1967: 307). No matter that these plates show a creature clearly too small in the mouth to swallow Jonah. Melville's expositor, with access to more "scientific" whale depictions, will solve this difficulty by expanding on the assertions of one "Bishop Jebb" who claims that Jonah never reached the whale's belly but was "temporarily lodged in some part of his mouth." When, at this point, the doubting fisherman frets that surely the whale's digestive juices might then have had some pernicious effect on poor Jonah, his doubts are answered with additional pedantries tricked out as positive Bible science. But when the sailor then questions the improbably foreshortened three-day journey from Joppa to Nineveh, Melville's hapless divine will finally, contradictorily, upbraid the Sag Head sailor for his "foolish pride of reason" (308). Here orthodox positivism dead-ends, for while the orthodox interpreter would prove the historical veracity of the Scriptures, preserving their authority by affirming their literal truth, he must reserve a case against human reason when the tools of logic cut too finely. Flustered, he appeals to evidence supplied by "Catholics" and "Turks," heretics here hastily promoted to the status of the "highly enlightened" (308). The orthodox hunt for a one-to-one correspondence between letter and spirit, a perfect alignment of historical signifier and spiritual signified, does nothing but unseat the spirit. The harder one presses the biblical texts, the more they look like fish stories, the less like gospel truth; the more one relies on positive biblical science, the more rickety the dogma propped up by this science becomes. 
By all accounts, and as his full oeuvre makes it hard to gainsay, Melville had considerably more sympathy for liberal theologians than for their orthodox opponents. Yet he does not scruple to reveal the sometimes narcissistic glibness of the liberal exegete. As he argues in chapters like "The Spirit Spout" and "The Blanket," liberals will too often mistake their own lights for the text's, too often mistake the interpretive medium for the body and substance of truth. Infatuated with "inspiration," liberals mistake their own flights of imagination for divine afflatus. Thus, "while composing a little treatise on Eternity," Melville writes, "I had the curiosity to place a mirror before me, and ere long saw reflected there, a curious involved worming and involution in the air above my head" (314).

Further, insofar as imaginative ether is an element saints and sinners imbibe, the search for spirit-a Faustian enterprise-may make bedfellows of philosophers and devils. Every spirit hunter may find his air castle "glorified by a rainbow, as if Heaven himself had put its seal upon his thoughts" (314)-with baleful consequences. For when, Melville suggests, we mistake our own effulgent thought for the world's dreaming, we may account the sea's face more welcoming than it materially is. Ishmael on the masthead twice loses mastery of his own head-and nearly loses his life-when he forgets that the sea's surface may reflect, even soften, our own faces, while sheathing its own adamantine otherness. The dreamer falling from great heights into his own reflection will find the water as hard as duller fellows do.

Sometimes, as Melville shows, the liberal interpreter's rudest awakening is to find himself dressed in his opponent's cassock. The intellectual pleasure of the allegorical procedure can so distract that, caught up in the spiritual eloquence of the whale's flesh, the liberal will-as in "The Blanket"-contrive a moral he might not endorse in more sober moments. His head turned, the foolish liberal vaunts: "Do thou, too, live in this world without being of it! Be cool at the equator; Keep thy blood fluid at the Pole" (261). This nostrum of weaned affections is, of course, a Calvinist cliché and orthodox truism, but the dreamy exegete has nothing to blame for it but his own liberal method. Those who are too easily drawn into hermeneutic circles, finding in the text what they expect to find, may be foiled by their own projecting hubris.

While rife with such exercises in intellectual satire, Moby-Dick is, certainly, less a compendium of clerical faux pas than a drama of character. It is a book that gives names and flesh, personality, motive, and, consequently, ethical accountability to searchers for truth without wisdom. Moby-Dick will show the characterological-and, by extension, institutional-consequences of Hellenism's tendency to reduce all else to 
essence's waste product, making all else tributary to its horizon-to-horizon prospect. Specifically, Melville incarnates this allegorical power in Father Mapple, the preacher-seaman, and in Captain Ahab, the seaman-preacher. Through them he shows how allegorical method makes violent defilers out of Hellenic adepts, thus divinizing the violent and sanctifying their violence. Ahab and Mapple, cousins of the "archbishoprick" with whom I began, are cautionary embodiments of the urge to totalize. Both are fiery evangelists deploying the Pauline device of textual unification. No accident, then, that Ahab's most affecting speech, offered in "The Quarterdeck," hews to rather orthodox contours. There Ahab posits a physical, or phenomenal, world whose meaning flows up from a noumenal substrate. His essentialist view, offered in the classical idiom, is that the random appearances of the world are united by one meaning, or Logos, the apprehension of which requires violent penetration and rending of the historical and phenomenal integument: "Hark ye yet again - a little lower layer. All visible objects, man, are but as pasteboard masks. But in each event-in the living act, the undoubted deed there, some unknown but still reasoning thing puts forth the moulding of its features from behind the unreasoning mask. If man will strike, strike through the mask!" (144).

Ahab's extremist metaphysics might be dismissed as mere symptoms of his madness were it not that the selfsame, essentially violent, Hellenism is articulated earlier in the book from the very prow of Christianity by its consecrated minister, Father Mapple. Taking Jonah's travail as his text, the Hellenist Mapple gestures at Being through the offices of a lamp in Jonah's cabin.

Screwed at its axis against the side, a swinging lamp slightly oscillates in Jonah's room; and the ship, heeling over towards the wharf with the weight of the last bales received, the lamp, flame and all, still maintains a permanent obliquity with reference to the room; though, in truth, infallibly straight itself, it but made obvious the false, lying levels among which it hung. ... The floor, the ceiling, and the side are all awry. " $\mathrm{O}$, so my conscience hangs in me! he groans, straight upward, so it burns, but the chambers of my soul are all in crookedness."

Father Mapple's allegory of Jonah's travail is based on the same ontological impatience, and is marked by the same sublime allegorizing, as Ahab's homily on the whale. His homily makes the truth, to use terms crucial later in the book, a "fast fish" - owned, controlled, and secured by the clerical functionary whose authority may grow in exact proportion to the esotericism of his "lower layer." Interpreting a story about disobedience, and ostensibly reproving the scriptural Jonah for his hubris, Father Mapple nevertheless winds up his sermon with a celebration of the steadfast ego: "Delight is to him-a far far upward and inward delight - who 
against the proud gods and commodores of this earth, ever stands forth his own inexorable self. Delight is to him whose strong arms yet support him when the ship of the base treacherous world has gone down beneath him. Delight is to him, who gives no quarter in the truth and kills, burns and destroys all sin" (51).

Affixed a posteriori to the steadfastness of the inexorable self, the Lord's authority is employed to launder an all-too-familiar Protestant hubris: The purposes of the self are scribbled over the Lord's forged signature, as the archbishoprick lights leaves with leaves, truth with the history of truths.

In these tableaux of the Hellenist as human manqué-Ahab pegged to one point on the deck, Father Mapple in his roped-off perch-Melville discovers not only the solipsism and sterility but also the sacrificial imperative, the hostility to history, and, finally, the will to institutional aggrandizement that are concealed beneath the search for pure Being. Spirit spout and try-pot send up one oily flame, burning all flesh by one light.

As I want to show now, genuine sanctuary from these dark theological mills is to be found only in an embrace of history which, because always local, must always be revised according to present circumstance. Carlyle's metaphor for such revision is the "tailoring" that makes truth literally suitable to the exigencies of a particular time and place. In Moby-Dick, a book whose debt to Carlyle is profound, this historically specific strain of truthwith-its-blubber-on appears in the guise of cetology, the practical science of whales. In Moby-Dick, cetology harbors and protects both the loose fish and the stray letters that theology must - for the love of reason-spear, submerge, and consume.

\section{Hebraism: Theology to Cetology}

Melville's skepticism about the spirit spout of Christian Hellenismwhether expressed in tableaux of Ahab's baroquely romantic depredations on the truth or in Father Mapple's logocentric tropisms of burning and killing - is counterpointed, as I have intimated, by the prolixity of the very text that contains them. In this text, the extravagances of the wandererscribe merge into those of all his interpretive precursors, so that whereas Ahab and Mapple literally rope themselves off in pursuing their versions of pure and unitary truth, Ishmael's knowing takes momentum and energy from its very promiscuousness. Melville's historical eclecticism, his conviction that the way is in rather than through the letter, and, finally, his fascination with syntheses of action and precept in wisdom-all these inform the Hebraic structure, style, and matter of a text devoted to rescuing Ishmael from Ahab's Hellenic captaincy. 
Melville's Hebraisms are, I believe, many, but three I have already introduced will suffice here to suggest the extent of Melville's "unchristian . . . wickedness." First, there is the Hebraism he found modeled in Kitto's Cyclopaedia of Biblical Literature; second, that which he found in the work of Carlyle, a writer renowned for his Old Testament ethics; and finally, that which he absorbed in his readings in the Hebrew wisdom literature, especially Ecclesiastes. These Hebraisms - call one methodological, the second ethical, and the third philosophical-shape Ishmael's pursuit of a kind of knowledge inimical to Ahab's. These Hebraic models inform his identity as a piler up of books and behaviors, his identity as a walker on many legs to Ahab's unbalanced one. Indeed, if Ahab's literal amputation from the world of substance and prudential action is emblemized in his having only one leg to stand on, Ishmael's circumnavigatory rhetoric describes a mode of gaining truth not through immediate knowledge but by applicative and peripatetic labor.

Ishmael's devotion to Hebraic method is established from the opening pages of the book. There Melville, imitating biblical philologists of the day, inaugurates his telling in encyclopedic, rather than testamentary, fashion, drawing on the particular positivistic and comparative methods he found modeled in such works as John Kitto's history-drunk Cyclopaedia of Biblical Literature, which he kept by his side during the composition of Moby-Dick. From his copiously documented introduction, Kitto is at pains to show that the proper aim of hermeneutics is not the discovery of an allegorical Word-not the discovery of "revealed doctrine which has long since been completed." Rather, interpretation ought to pursue a more developmental, or historical, view of the text, which, "like the human mind itself, is continually expanding in youthful vigor, [and] which, when correctly comprehended, exhibits a mutual relationship and degree of development with whatever stage of culture and civilization its adherents might have reached" (Kitto 1845: xi).

Following Kitto's lead, Melville's opening chapter eclipses "original" knowledge with positive, technical, or applied knowledge. He arranges around his whale a disunified sheaf of Bible leaves, of letters that are not assimilable to any unifying spirit but require the active and sustained process of learning. Any theory of knowledge that does not accommodate the historicity, and thus diversity, of the known will, in Melville's text, be left to assert what primacy it can muster against and amid diverse phenomenaindeed, against diversity's inherent and formidable power to make relative all claims. Thus, in his opening chapter, "Etymologies," Melville surveys the words for whale in various cultures, imitating, as Thompson suggests (1952: 187), the self-consciously philological frontispieces commonly af- 
fixed to nineteenth-century Bibles, but also mocking - with Kitto - the dogmatic bad faith that would mistake cognitive conscientiousness for immediate access to truth. In a catalog in which the Hebrew han, the Latin cetus, the Anglo-Saxon whoel, the Danish hvalt, and the English whale share space with the Feegee pekee-nuee-nuee and the marginally different Eromangoan pehee-nuee-nuee, Melville offers a simple demonstration of the well-traveled experience of the signifier. He hints, as well, at the anxiety small differences of the letter may occasion. Cannily, Melville places at the center of his etymological survey Hakluyt's pedantic screed against the dropping of the $H$ in the English word whale: "While you take in hand to school others, and to teach them by what name a whale fish is to be called in our tongue, leaving out, through ignorance, the letter $\mathrm{H}$, which almost alone maketh up the significance of the word, you deliver that which is not true" (1).

The feebleness of this scholarly codicil is, of course, exposed by the actual orthographic variety of the words among which it is included, and especially by the closing two entries, where the discrepancy of one letter ( $h$, as it happens!) explicates the letter's role as one not so much of securing ontological meaning as of defining jurisdictions of meaning. The difference between pekee and pehee is, we may infer, only that between its rivalrous namers. In addition to this demonstration, at Hakluyt's expense, of knowledge's hardly disinterested will to power, the tenuousness of Hakluyt's position is underscored by the provenance of his own utterance. Like all of the other etymological proofs, Hakluyt's alarm is unearthed by a minor scribe, a researching drone, "a late consumptive usher to the grammar school," whose dubious reliability corrupts that of his sources as well. History, Melville opens by implying, is a palimpsest of vehemencies like Hakluyt's, each asserting its own claim to original and authoritative power. Positive dictionary definitions of whale collected by the late consumptive usher to the grammar school offer not evidence but only one generation's rough surmise of reliable truth. Truth claiming any greater privilege than this-moreover, truth flexing its muscles, as in Hakluyt's screed-must naturally compromise its claim to disinterest and to self-evidence as well.

The next chapter, "Extracts," exacerbates the crisis of authority by introducing the consumptive usher's doppelgänger in the person of the hapless "sub-sub," seeker after veritable "gospel cetology": "It will be seen that this mere painstaking burrower and grubworm of a poor devil of a subsub appears to have gone through the long Vaticans and street stalls of the earth picking up whatever random allusions to whales he could anyways find in any book whatsoever, sacred or profane. Therefore you must not, in every case at least, take the higgledy piggledy whale statements, how- 
ever authentic, in these extracts for veritable gospel cetology" (2). In the sub-sub's redacted text, extracts from the Bible share space with "something unpublished." Poetry is juxtaposed with philosophy; history, with bogus science; indifferent snippets from Shakespeare, with Nantucket ballads. All these are joined in a loose-linked survey of authorities that gives special prestige to no one text. Again, if the extracts are "promiscuous," the dubious qualifications of the sub-sub are, in the end, no worse than those of his sources. The elapsing of time necessarily confers on all claims to immediate revelation the same mediate, because superannuated, status. To be sure, as readers of Moby-Dick are often discomfited to note, Ishmael himself in later chapters becomes indistinguishable from the sub-sub who was the pitiful object of his earlier derision. History annexes tellers to their texts, ultimately robbing them of the personal authority through which they once asserted their truth claims. These claims, now yellow and papery, now reliant on intellectual functionaries rather than true believers, must speak for themselves.

Kitto's contribution to Melville's work is largely methodological. Kitto helps Melville to adumbrate the epistemological necessity of the historical, or Hebraic, method that Melville will, with the help of Carlyle, go on to refashion into a virtue. For to point out the leveling of knowledge along the path of the letter is not to dismiss the letter's value. Quite the reverse. Melville learns from Carlyle that in acknowledging the variety and historicity of experience-including its elusiveness and opacity-one may lose the "all" but gain, in compensation, a new regard of how knowledge can be turned to insight, a sense of how applied truth can be serviceable in ways that the naked truth is not. History does not just lay on truth as its arbitrary integument; it gives truth bearing, gives knowledge "clothes." While Kitto, in conclusion, apprises Melville of a Hebraic method commodious enough for the vagrant erudition of Ishmael, Carlyle offers him the mode of human conduct such a method supports.

Recall, then, that Carlyle, whose stylistic influence has long been counted as seminal for Melville's Moby-Dick, had written his own Sartor Resartus as a philosophy on clothes, an apology and a full-throated clarion "yea" on behalf of the truth's blanket-or, if you will, its "blubber." Sartor Resartus champions the valor of walking in the text's way, of taking shade from its eternal flourishing, of tailoring the truth rather than disclosing its nakedness. In Carlyle's Hebraic formulation, the excellence of the Book necessarily trumps that of some occulted original Word. "Wondrous indeed," Carlyle proclaims in a typical passage, is the

virtue of a true Book. Not like a dead city of stones, yearly crumbling, yearly needing repair; more like a tilled field, but then a spiritual field: like a spiritual 
tree, let me rather say, it stands from year to year, and from age to age (we have Books that already number some hundred and fifty human ages) and yearly comes its new produce of leaves (Commentaries, Deductions, Philosophical, Political systems; or were it were only Sermons, Pamphlets, Journalistic essays) every one of which is talismanic and thaumaturgic. . . . Fool! who journeyest thou wearisomely, in thy antiquarian fever, to gaze on the stone pyramids of Geeza, or the clear ones of Saccara. (Carlyle 1831: 138)

Such passages move Rowland Sherrill and Albert Lavalley to draw explicit links between Ishmael's wider "ambit" and Carlyle's own belief in a supernatural mystery whose "natural" emanations are all we can grasp. As Carlyle's Teufelsdrokh comes to a revelation of truth inferred through the handiwork of its articulation, so Melville's attachment is not to the truth's nakedness but to the hand and texture history give, the dimensionality and praxis history affords. Melville's own Carlyle-inspired description of truth as a temple of usage comes in "The Bower of the Arsacides." Here Ishmael gives his account of the discovery of a certain beached whale that, decomposed and fallen skeletal amid the verdure of a coconut grove, becomes the sanctuary of a spiritualized cultural practice as its bones are dressed with the overgrowth of history and usage. Like Carlyle's apostrophized book, a loom effulgent with relettering, Melville's skeletal whale is "hung with trophies," its vertebrae with Arsacidean annals in "strange hieroglyphics." As the deposit of culture fills the empty rib cage, Melville's language is itself woven with Carlyle's:

The industrious earth below was as a weavers look, with a gorgeous carpet on it, whereof the ground vine tendrils formed the warp and woof, and the living flowers the tendril. . . . Now amid the green, lifeless loom of that Arsacidean wood, the great white worshipped skeleton lay lounging - a gigantic idler. Yet as the ever woven verdant warp and woof intermixed and hummed around him, the mighty idler seems a cunning weaver . . . every month assuming greener fresher verdure. (374)

This emblem of empty truth draped in lush verdure inverts the horrific image of Thirwall's mutilated Logos. It replaces the decomposed theology that history cannot but ravage with a growing "cetology" newly dressed season by season. By such means, Melville makes out of Higher Critical decomposition a principle of composition; the Scripture's very unraveled yarn becomes the fiber of its continuity.

In this same connection, we should mark carefully how the chapter honored with the title "Cetology" returns to the Thirwallian figure of dismembered truth. In this key chapter, Melville challenges the same theological truism its title spoofs (substituting for the transcendent theo the corporeal ceto) by presenting us with yet another model of the mammoth/ 
monument in dishabille, another airy-ribbed skeleton subject to history's warpage in all senses of the word. The chapter begins in Christian good earnest, promising a "classification of the constituents of a Chaos" (117), its writer "[groping] down to the bottom of the sea . . . to have one's hands among the unspeakable foundations, ribs and very pelvis of the world" (118). But this zealous pursuit of origins quickly loses steam as he begins to list his precursors in the enterprise; the list of expert witnesses eclipses his "ultimate generalizing purpose." Sanguine in defeat, Ishmael then steps before the scenery to characterize his technique:

Finally, it was stated at the outset that this system would not be here, and at once, perfected. You cannot but plainly see that I have kept my word. But I now leave my cetological system standing thus unfinished, even as the great Cathedral at Cologne was left. . . . For small erections may be finished by their first architects; grand ones, true ones, ever leave the copestone to posterity. God keep me from ever completing anything. This whole book is but a draughtnay, but the draught of a draught. (128)

As it happens, the cathedral at Cologne, a locus classicus of romantic attention, was particularly galling to Goethe, for whom, as Hans Frei notes in The Eclipse of Biblical Narrative, "the Cologne Cathedral, frozen in unfinished state hundreds of years earlier, was like a ruin to his eyes" (202). Goethe's depression derived from the cathedral's assertion of a brute kind of historical virtuality against the poet's desire to conflate time - in Coleridge's gloss, to get "the past and the present in one" (203). For Goethe, the source of meaning must be found in a unity that transcends historyas the biblical text of Herder transcends its historical inconsistencies. For Melville, a writer growing increasingly skeptical of Goethe and what he described to Hawthorne as Goethe's "flummery" $(560)$, the Cologne cathedral's beauty lies in these very inconsistencies, in its unfinished character. And so the virtue of his own composition. Deeming Goethe's idealized unity as defunct as the unitary creation of Genesis, obsolete as the original plan for the Cologne cathedral, Melville offers a kind of knowledge eternally open to the revisions of posterity: a draft, subject to effacement or relativization by the accretion of history.

Throughout Moby-Dick, as I have been arguing, Melville demonstrates and defends the teaching of the scribes: that is, the wisdom produced by the assiduous labor of sub-subs who are both limited by the contingencies of history and beneficed by the multifariousness of interpretive possibility. Melville's advocacy of textual density is cognate with the belief in practice as knowledge, with truth ultimately secured in application or particular embodiment. In the course of writing Moby-Dick, his faith in the Platonic, or eternal, verity ebbed more and more, to the point that he wrote to Haw- 
thorne, "What plays mischief with the truth is that men will insist on the universal application of a temporary feeling or opinion" (560). Melville's growing faith in the seasonality, or historicity, of truth was only enhanced by his readings in Ecclesiastes, a text he found increasingly compelling. "I read Solomon more and more," he wrote to Hawthorne, "and every time see deeper and deeper and unspeakable meanings in him" (559).

To be sure, as all the foregoing pages have been devoted to showing, Melville's book devolves and expands itself out from the same paradox that undergirds the book of Ecclesiastes. Like "Solomon," Melville's Ishmael meets the apparent vanity of human action with action and meets the apparent limitations on human effort with work and observance. Usages, while floating on nothing (as the Pequod itself floats on the ocean), still give men footing, a stretch of water to harvest, a piece of earth to hoe. As all the multifarious usages and routines of the whale ship give employment to men otherwise vagrant in time, Melville buoys up Ishmael on the twin life preservers of reflection and action, word and work. As Ishmael's action is articulate, his speech is efficacious; his very garrulity is a creditable kind of handiwork.

Ishmael's scribalism, though, has further, final implications. When Paul says of Jesus, "He taught as one having authority; not as one of the scribes" (Matthew 7:29), the distinction he makes is between one whose knowledge transcends the sequence and effacements of history and one whose knowledge does not. But more, his distinction is between one who sees truth obscured by precedent action and one who sees truth realized in it. The brunt of Paul's comparison, of course, falls on the Hebrews. It is their legalism, their belief in action as sufficient articulation, their refusal to gather words into Word, that he perceives Christ to rebuke and transcend. Melville's interest in the status of law and his defense of articulation virtualized in action directly contradict the Pauline paradigm. Indeed, Melville's Hebraism extends, I want to propose, to a defense of truth's accountability to and fertilization in law - that is, in idea ratified by practice. For Melville, both acts and words become part of a historical body of precedent and practical knowledge with purview over and conversance with the hearkening present.

The "dead letter," or stigmatized Hebraic precedent (its symbol Queequeg's richly lettered coffin, on which Ishmael floats until rescued by the Rachel), is, contra Paul's way, a law for living. For the Hellenist Paul, law attenuates agape in the routines of conduct, degrades kairos in chronos. For the Ecclesiast and the Ishmaelic scribe, in contrast, the law is a record of the way walked; moreover, it is the way of all walking. Law, as Melville invokes it in numerous chapters ("His Mark," "The Advocate," "The Affi- 
davit," "Fast Fish and Loose Fish," "Head or Tails," to name just a few), recalls us not to any absolute beyond application but to the absolute of application. Law is not the descent of truth into substance but the foundation of truth as substance. When, therefore, Melville devotes himself in such chapters to enumerating, sometimes flat-footedly, the norms and practices that would support one case or another, his "advocacy" is informed by a belief in the relevance of only that truth which can be made immanent, which can be vernacularized, by and in human usage. That is why the "The Advocate" is composed as a dialogue with an interlocutor and why "The Affidavit" consists of a sheaf of evidences not weakened, but strengthened, by diversity and topicality. If Ahab seeks truth through a searing and transfixing vision of his synchronic "chart," Ishmael would instead secure wisdom by means of more digressive "higgledy-piggledy" researches, themselves an occupation and a way. To presume ever to catch truth out of time, to presume that one may make it a "fast fish," is not only to contradict human experience; it is also to blaspheme by evading the discipline that experience confers. The human walker, the Ishmaelite, Melville counsels, ignores such wisdom at his peril. Thus, it is a version of the Ecclesiast's legalistic wisdom - "Fear God, and keep his commandments for this is the whole duty of man"-rather than of the Apostle's transcendent knowledge - "Christ redeemed us from the Curse of the Law" (Galatians 3:13) - that finally saves Ishmael from Ahab's fire.

Recall that in the opening pages of the book, Ishmael had put off spell of the hypos, a death wish, with a course of diversionary reading and a period of busyness at sea. At the end, he will escape the vortex by clinging to the still-buoyant, though opaque and obscure, coffin of his brother, Queequeg. But at the exact center of the book, Ishmael's final survival is already suggested, and the wisdom of his initial course confirmed, in his responsiveness to a Solomonic word. For there, at the try-pots where this essay began, Ishmael suffers a vision of hell, in which "the rushing Pequod, freighted with savages, and laden with fire and burning a corpse, and plunging into that blackness of darkness, seemed the material counterpart of her monomaniac commander's soul" (354).

Converted momentarily to an allegorist after Ahab's dark training, Ishmael falters, and a "stark, bewildered feeling, as of death came over me" (354). Yet this feeling, a bit of the hypos, passes. This convulsion of allegory, Ishmael rouses himself to realize, is but a "hallucination of the night." Apostrophizing "Look not too long into the face of the fire," he clings to this paraphrase of Ecclesiastical wisdom: "Tomorrow in the natural sun, the skies will be bright; those who glared like devils in the forking flame, the morn will show in far other, at least gentler relief" (354). He closes the 
chapter with this citation: "The truest of all men was the man of sorrows, and the truest of all books is Solomon's. Ecclesiastes is the fine hammered steel of woe. This wilful world hath not got hold of unchristian Solomon's wisdom yet. . . . But even Solomon says, the 'man that wandereth out of the way of understanding shall remain in the congregation of the dead. ... There is a wisdom that is woe, but there is a woe that is madness" " (355).

Fortified with this Hebraic wisdom - the wisdom that, in fact, there is a "time for every purpose under heaven; a time to be born and a time to die"-Ishmael sails on to find in words not a Word, but more words still. If Paul gave Melville's compeers materials out of which to fashion an essentialist idealism, a nineteenth-century Christian Hellenism based on the quests for the "spirit," in the unorthodox Ecclesiastes Melville discovers a more heterodox wisdom and a version of that pragmatism to which even Emerson is, in the end, converted.

Moby-Dick's literalism is Melville's sustained tribute to "unchristian Solomon." The book's structure, which forgoes perfection for the sake of "a draught-nay, but the draught of a draught," vibrates with both the Ecclesiast's despair at finishing anything and the rewards of sustaining a tradition of writing. For if allegory is finally, for Melville, an apocalyptic mode - and a violent one, burning the truth with the Bible leaves - his Ecclesiast toils on, living through the apocalypse of metaphor to say, "And only I am escaped alone to tell thee." The authority that unifies the text under one meaning is replaced by a more ephemeral authority: that of the sub-sub, messenger, or scribe, who would rather tailor wisdom than boil it down. In practice, this Hebraic scribe drapes with his own colors the skeletal truth that only history can make into a living bower.

\section{References}

Abrams, M. H.

1971 Natural Supernaturalism: Tradition and Revolution in Romantic Literature (New York: W. W. Norton).

Alter, Robert, and Frank Kermode, eds.

1987 The Literary Guide to the Bible (Cambridge, MA: Harvard University Press).

Bercaw, Mary 1987 Melville's Sources (Evanston, IL: Northwestern University Press).

Bercovitch, Sacvan, ed. 1986 Reconstructing American Literary History (Cambridge, MA: Harvard University Press).

Bickerman, Elias 1967 Four Strange Books of the Bible (New York: Schocken).

"A Bishop's Benediction" 1850 Christian Register, April 27.

Braswell, William

1943 Melville's Religious Thought: An Essay in Interpretation (Durham, NC: Duke University Press). 
Brodhead, Richard, ed. 1986 New Essays on Moby-Dick (Cambridge: Cambridge University Press).

Brown, Jerry Wayne 1969 The Rise of Biblical Criticism in America, 1800-1870 (Middletown, CT: Wesleyan University Press).

Brumm, Ursula

1970 American Thought and Religious Typology, translated by John Hoagland (New Brunswick, NJ: Rutgers University Press).

Buell, Lawrence 1986 New England Literary Culture (Cambridge: Cambridge University Press).

Carlyle, Thomas 1905 (1831) Sartor Resartus, The Life and Opinions of Herr Teufelsdrockh (New York: Scribners).

Cavell, Stanley 1972 The Senses of Walden (New York: Viking).

Colacurcio, Michael 1984 The Province of Piety: Moral History in Hawthorne's Early Tales (Cambridge, MA: Harvard University Press).

Cowan, Bainard 1982 Exiled Waters: Moby-Dick and the Crisis of Allegory (Baton Rouge: Louisiana State University Press).

Derrida, Jacques 1992 The Gift of Death, translated by David Wills (Chicago: University of Chicago Press).

Douglas, Ann 1977 The Feminization of American Culture (New York: Anchor).

Frei, Hans 1974 The Eclipse of Biblical Narrative (New Haven, CT: Yale University Press).

Frye, Northrop 1957 The Anatomy of Criticism (Princeton, NJ: Princeton University Press). 1982 The Great Code: The Bible and Literature (New York: Harcourt Brace Jovanovich).

Goldman, Shalom 1993 Hebrew and the Bible in America: The First Two Centuries (Hanover, NH: University Press of New England).

Gunn, Giles 1979 The Interpretation of Otherness: Literature, Religion, and the American Imagination (New York: Oxford University Press).

Handelman, Susan 1982 The Emergence of Rabbinic Interpretation in Modern Literary Theory (Albany: State University of New York Press).

Herbert, T. Walter 1977 Moby Dick and Calvinism (New Brunswick, NJ: Rutgers University Press).

Honig, Edwin 1959 Dark Conceit: The Making of an Allegory (Evanston, IL: Northwestern University Press).

Ikeler, A. Abbot 1972 Puritan Temper and Transcendental Faith: Carlyle's Literary Vision (Columbus: Ohio State University Press).

"John Foster's View of the Bible and the Future State" 1849 Christian Register, January 29.

Kitto, John 1845 Cyclopaedia of Biblical Literature (New York: Mark H. Newman).

Lavalley, Albert J. 1968 Carlyle and the Idea of the Modern (New Haven, CT: Yale University Press).

"Lost Verse of the Bible Restored" 1850 Christian Register, January 5. 
Melville, Herman

1967 Moby-Dick; or The Whale: A Norton Critical Edition, edited by Harrison Hayford and Hershel Parker (New York: W. W. Norton).

New, Elisa

1993 The Regenerate Lyric: Theology and Innovation in American Poetry (Cambridge: Cambridge University Press).

Parker, Hershel, and Harrison Hayford 1970 Moby-Dick as Doubloon (New York: W. W. Norton).

Quarterly Review 1848 Review of Neander's Life of Christ, July.

Schleiermacher, Friedrich 1825 A Critical Essay on the Gospel of St. Luke: With an Introduction by the Translator, Connop Thirwall (London: John Taylor).

Scott, R. B. Y.

${ }_{1965}$ Proverbs-Ecclesiastes, Anchor Bible (Garden City, NY: Anchor).

Sealts, Merton M.

1988 Melville's Reading, rev. and enl. ed. (Columbia: University of South Carolina Press).

Shaffer, E. A.

1975 "Kubla Khan" and "The Fall of Jerusalem": The Mythological School in Biblical Criticism and Secular Literature, 1770-1880 (Cambridge: Cambridge University Press).

Sherrill, Rowland

1972 The Prophetic Melville: Experience, Transcendence, and Tragedy (Athens: University of Georgia Press).

Thompson, Lawrence

1952 Melville's Quarrel with God (Princeton, NJ: Princeton University Press).

Wright, Natalia

1949 Melville's Use of the Bible (Durham, NC: Duke University Press).

Zoellner, Robert

1973 The Salt-Sea Mastadon: A Reading of Moby-Dick (Berkeley: University of California Press). 